\title{
QUANTIFICATION OF CEREBROSPINAL FLUID FERRITIN AS A BIOMARKER FOR CNS MALIGNANT INFILTRATION
}

\author{
Sérgio Monteiro de Almeida, Dione Sosnitzki da Cunha, \\ Edna Yamada, Elvira Missako Doi, Margaret Ono
}

\begin{abstract}
Several markers have been studied for their ability to make the CNS infiltration diagnosis earlier and more precise; previous studies showed that CSF ferritin concentrations were higher in patients with malignant invasion of CNS. The objective was to determine the importance of CSF ferritin as a biomarker for the diagnosis of CNS neoplasic infiltration. This study is based on 93 CSF samples, divided into five groups: malignant cells present (n13); malignant cells not present (n26); inflammatory neurological diseases (n16); neurocysticercosis ( $\mathrm{n} 20$ ); acute bacterial meningitis (n18). CSF ferritin values were determined by micro particle enzyme immunoassay. CSF ferritin level (mean \pm SD) in the group with neoplasic cells in the CSF was $42.8 \pm 49.7$ $\mathrm{ng} / \mathrm{mL}$, higher than in the other groups $(p<0.0001)$. We conclude that CSF ferritin with the cut off $20 \mathrm{ng} / \mathrm{mL}$ could be an adjuvant biomarker to the diagnosis of CNS malignant infiltration.
\end{abstract}

KEY WORDS: cerebrospinal fluid, ferritin, central nervous system, malignant cells, CNS neoplasm, CNS tumors, bacterial meningitis.

\begin{abstract}
Quantificação de ferritina no líquido cefalorraquidiano como biomarcador para o diagnóstico de infiltração maligna no SNC

Resumo - Diversos marcadores foram estudados com a finalidade de avaliar sua capacidade de diagnosticar a infiltração neoplásica no SNC precocemente e de forma mais precisa. Estudos anteriores mostraram que as concentrações de ferritina no LCR eram mais elevadas nos pacientes com infiltração neoplásica no SNC. 0 objetivo foi determinar a importância da ferritina no LCR como biomarcador para o diagnóstico de infiltração neoplásica no SNC. Este estudo é baseado em 93 amostras do LCR, divididas em cinco grupos: células malignas presentes (n13); células malignas ausentes (n26); doenças neurologicas inflamatórias (n16); neurocisticercose (n20); meningites bacterianas agudas (n18). Os valores de ferritina no LCR foram determinados por ELISA de microparticulas. O nivel de ferritina no LCR (média \pm desvio padrão) no grupo com células neoplásicas no LCR foi $42,8 \pm 49,7 \mathrm{ng} / \mathrm{mL}$, mais elevado do que nos outros grupos ( $p<0.0001$ ). Concluímos que a ferritina no LCR com cut off de $20 \mathrm{ng} / \mathrm{mL}$ pode ser um biomarcador para o diagnóstico de infiltração maligna no SNC.
\end{abstract}

PALAVRAS-CHAVE: líquido cefalorraquidiano, sistema nervoso central, células malignas, neoplasias do SNC, tumores do SNC, meningites bacterianas.

The cerebrospinal fluid (CSF) biochemical and cellular characteristics are important adjunct biomarkers for the diagnosis of the central nervous system (CNS) malignant infiltrations. Any type of malignant disease can spread to the leptomeninges ${ }^{1,2}$.

There is prevoius evidence that increased serum ferritin levels may be used as an indicator of malignant disease $^{3-6}$. Ferritin is present at very low concentrations in normal CSF. Previous studies showed that CSF ferritin concentrations were higher in patients with malignant inva- sion on the CNS than in patients without CNS involvement $^{7-9}$. High values of ferritin were also found in non-malignant diseases, such as infectious meningoencephalitis, CNS vascular diseases, and dementia ${ }^{10}$.

The hypothesis of CNS involvement by malignant neoplasms must be done in a patient with known malignant neoplasms and neurological symptoms". Because of the difficulty in early diagnosis of CNS involvement in malignant diseases, several markers have been studied for their ability to make the CNS infiltration diagnosis earlier and more precise ${ }^{12-15}$.

Clinical Pathology Laboratory, Hospital de Clínicas, Universidade Federal do Paraná, Curitiba PR, Brazil.

Received 12 May 2008. Accepted 19 July 2008.

Dr. Sérgio Monteiro de Almeida - Hospital de Clínicas / UFPR / Seção de Virologia / Setor Análises Clínicas - Rua Padre Camargo 280 - $80060-240$ Curitiba PR - Brasil. E-mail: sergio.ma@pop.com.br 
The objective of this study was to determine the importance of CSF ferritin as a biomarker for the diagnosis of CNS malignant infiltration. In order for this, we studied the levels of CSF ferritin in CSF samples with the presence of malignant cells and comparing them with the levels in samples with no malignant cells, inflammatory CNS disease, infectious diseases chronic and acute.

\section{METHOD}

All CSF samples were collected for clinical purposes by lumbar puncture. The Ethical Committee of the Hospital de Clínicas of Universidade Federal do Paraná approved this investigation.

The current study was based on 93 CSF samples, divided in five groups:

\section{Group 1}

Malignant cells present (n 13). Malignant disease with CNS involvement, diagnosed on the basis of presence of malignant cells in CSF. CSF samples from patients with clinical suspicion of malignant CNS infiltration and from patients that underwent prophylactic intrathecal chemotherapy, mainly from hematology, bone marrow transplantation (BMT), neurology and neurosurgery services. The diagnoses were: spinal cord tumor (1); lung carcinoma (1); breast carcinoma (1); melanoma (1); chronic myeloid leukemia (5); acute linfoide leukemia (2); linphoma (2).

\section{Group 2}

Malignant cells not present (n 26). CSF samples from patients with clinical suspicion of malignant CNS infiltration and from patients that underwent prophylactic intrathecal chemotherapy, mainly from hematology, BMT, neurology and neurosurgery services without malignant cells detected in CSF. The diagnoses were: acute linfoide leukemia (23); lymphoma (1); Burkitt lymphoma (1); astrocitoma (1)

\section{Group 3}

Inflammatory neurological diseases (n 16), including Behçet disease (8); pseudotumor (2); Guillain-Barré syndrome (1); polineuritis (1); Vogt Koyanagui Harada disease (2); neurosarcoidosis (1); mitochondriopathy (1).

\section{Group 4}

Neurocysticercosis (n 20). CSF samples from patients with clinical suspicion of neurocysticercosis (NC), neuroradiologic characteristics of NC and positive CSF anti-cysticercosis ELISA.

\section{Group 5}

Acute bacterial meningitis ( $\mathrm{n}$ 18). CSF samples from patients with clinical suspicion of acute bacterial meningitis and CSF with increase of WBC number, predominium of neutrophils and low glucose.

CSF cytology and biochemistry characteristics in all five groups are indicated at Table 1. CSF ferritin values were determined by micro particle enzyme immunoassay (MEIA) AxSYM ABBOTT in undiluted CSF samples, it was required $200 \mu \mathrm{L}$ of CSF sample. The analytic sensitivity of the AxSYM ferritin assay was $1.0 \mathrm{ng} / \mathrm{mL}$.

CSF total protein (TP) was quantified by turbidimetric method of sulphosalicylic acid and CSF glucose was quantified by enzymatic method. CSF total cell count was assessed by a Fuchs Rosenthal chamber. For differential cell count and to detect the presence of malignant cells, CSF samples were concentrated by Cytospin. CSF samples were protein enriched with albumin. The slides were stained by May Grünwald-Giensa technique and analyzed by, at least, two trained researchers (SMA and EN). CSF samples with more than $50 \mathrm{RBC} / \mathrm{mm}^{3}$ were excluded.

\section{Statistical analysis}

The continuous variables were compared using non-parametric test. To compare all the five groups were used the Kruskal-Wallis test. The groups were compared two by two by the Mann-Whitney test. A p value $\leq 0.05$ was considered significant. The results were presented as mean \pm standard deviation (SD).

To evaluate the operational characteristics of CSF ferritin quantification was used the following formulas ${ }^{16}$ : sensitivity $[\mathrm{TrP} /(\operatorname{TrP}+\mathrm{FN})] \times 100$; specificity $[\mathrm{TN} /(\mathrm{TN}+\mathrm{FP})] \times 100$; positive predictive value $[\operatorname{TrP} /(\operatorname{Tr} P+\mathrm{FP})] \times 100$; negative predictive value $[\mathrm{TN} /(\mathrm{TN}+\mathrm{FN})] \times 100$; detection rate $\mathrm{TrP} /$ total tested; Youden index [(sensitivity + specificity) - 1]; error ratio (FP + FN)/TrP; combined error (FP + FN)/total tested. (TrP, true positive; TN, true negative; $\mathrm{FP}$, false positive; $\mathrm{FN}$, false negative).

Table 1. CSF cytology and biochemistry values (mean $\pm S D)$.

\begin{tabular}{|c|c|c|c|c|c|c|}
\hline Group & $\begin{array}{c}\text { With } \\
\text { malignant cells }\end{array}$ & $\begin{array}{c}\text { Without } \\
\text { malignant cells }\end{array}$ & $\begin{array}{c}\text { CNS inflammatory } \\
\text { disease }\end{array}$ & Neurocysticercosis & $\begin{array}{c}\text { Acute bacterial } \\
\text { meningitis }\end{array}$ & $p^{*}$ \\
\hline $\mathrm{N}$ & 13 & 26 & 16 & 20 & 18 & \\
\hline Leuco $/ \mathrm{mm}^{3}$ & $320 \pm 825$ & $1.2 \pm 1.4$ & $1.8 \pm 2$ & $22 \pm 42$ & $7822 \pm 13080$ & 0.001 \\
\hline $\mathrm{RBC} / \mathrm{mm}^{3}$ & $13 \pm 24$ & $7.5 \pm 16.2$ & $14 \pm 22$ & $1.2 \pm 3.5$ & $23 \pm 19$ & 0.005 \\
\hline $\mathrm{TP} \mathrm{mg} / \mathrm{dL}$ & $262 \pm 675$ & $34 \pm 36$ & $29 \pm 15$ & $56 \pm 54$ & $724 \pm 1512$ & 0.018 \\
\hline Glucose $\mathrm{mg} / \mathrm{dL}$ & $50 \pm 25$ & $57 \pm 8$ & $68 \pm 33$ & $57 \pm 18$ & $20 \pm 23$ & \\
\hline
\end{tabular}

*P calculated excluding group 5; Leuco, leucocytes; RBC, red blood cells; TP, total protein. 


\section{RESULTS}

CSF ferritin levels (mean $\pm S D$ ) in the group with malignant cells present in the CSF was $42.8 \pm 49.7 \mathrm{ng} / \mathrm{mL}$; in the group without malignant cells in the CSF was 13.0 \pm 16.9 $\mathrm{ng} / \mathrm{mL}$; in the group with CNS inflammatory disease was $6.4 \pm 3.6 \mathrm{ng} / \mathrm{mL}$; in the group with neurocysticercosis was $12.6 \pm 15.8 \mathrm{ng} / \mathrm{mL}$ and in the group with acute bacterial meningitis was $241.7 \pm 234.1 \mathrm{ng} / \mathrm{mL}$. Figure 1 shows CSF ferritin levels (mean $\pm S D$ ) in the five groups studied.

Comparing all the five groups with the Kruskal-Wallis nonparametric test there was a statically significant difference between the five groups $(p<0.0001)$. Comparing the group with presence of malignant cells in the CSF with each other group, the CSF ferritin was higher than in the group without malignant cells in CSF, CNS inflammatory disease and neurocysticercosis ( $p=0.02 ; 0.002 ; 0.02$ respectively).

The CSF ferritin of the group without malignant cells in the CSF was not statistically different from the CSF ferritin of the groups with CNS inflammatory diseases or neurocysticercosis but was different from the CSF ferritin in the group with acute bacterial meningitis $(p=0.37,0.89$, $<0.0001$ respectively). The CSF ferritin of the group with CNS inflammatory diseases and the group of neurocysticercosis was not different $(p=0.53)$. The CSF ferritin in the group with acute meningitis was greater than the ferritin from the other groups $(p<0.001)$.

The CSF ferritin in the group with more than $50 \%$ of malignant cells in the CSF was higher than the group with less than $50 \%$ of malignant cells in the CSF, 57.6 \pm 61.8 (median 26.9 ) and $36.2 \pm 47.5$ (median 12.4 ) respectively (Fig 2). Although there was no statistic difference $(p=0.18)$, probably because the low number of cases in each group ( 5 and 6 respectively).

The operational characteristics of CSF ferritin to detect CSF malignant infiltration with different cut-offs are showed at Table 2 .

The best cut-off for CSF ferritin is $20 \mathrm{ng} / \mathrm{mL}$, although

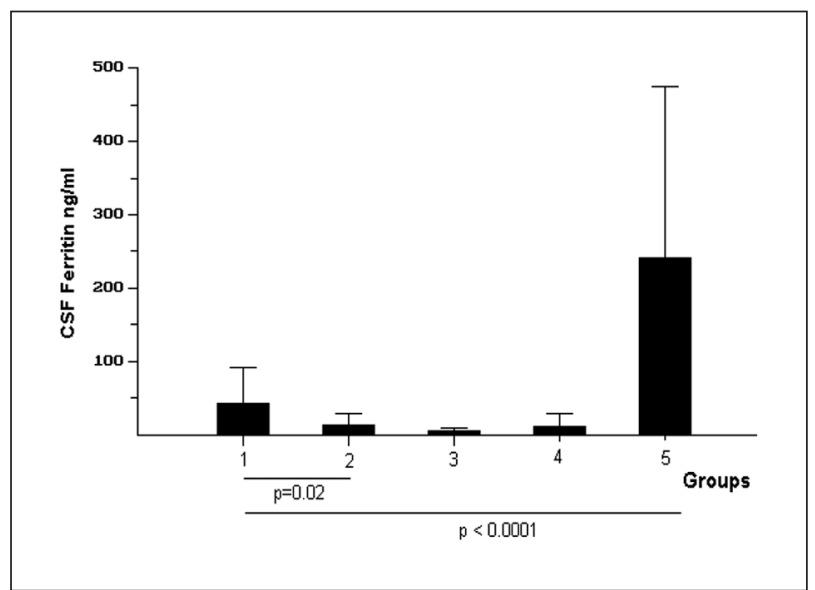

Fig 1. CSF ferritin levels $(\mathrm{ng} / \mathrm{mL})$. Values are mean and standard deviation.

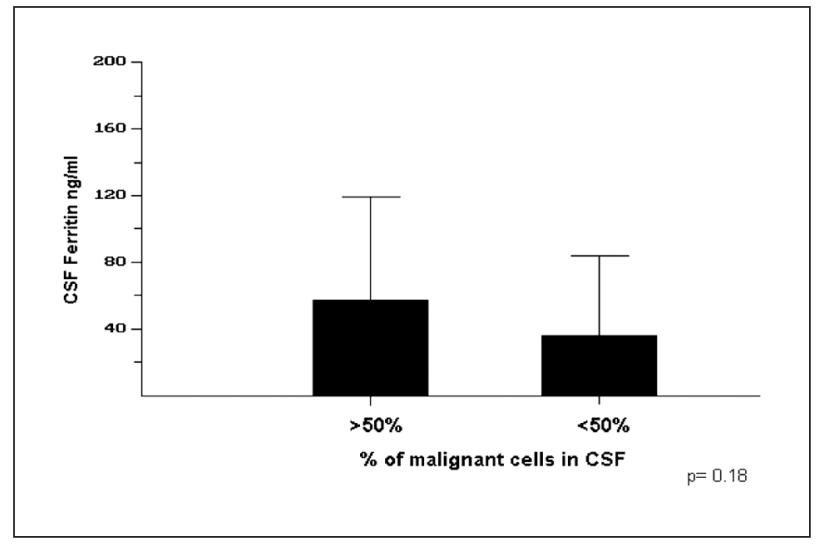

Fig 2. CSF ferritin levels and number of malignant cells in the CSF.

an increased CSF ferritin does not indicate the diagnosis of CNS neoplasic infiltration. Low CSF (less than $20 \mathrm{ng} /$ $\mathrm{mL}$ ) ferritin could be indicative of lesser chance of having CNS malignant infiltration, because the negative predictive value is higher with this CSF ferritin cut-off.

Table 2. Operational characteristics of CSF ferritin with different cut-offs.

\begin{tabular}{|c|c|c|c|c|c|}
\hline CSF Ferritin & $>5 \mathrm{ng} / \mathrm{mL}$ & $>20 \mathrm{ng} / \mathrm{mL}$ & $>40 \mathrm{ng} / \mathrm{mL}$ & $>60 \mathrm{ng} / \mathrm{mL}$ & $>80 \mathrm{ng} / \mathrm{mL}$ \\
\hline $\operatorname{TrP}(\mathrm{N})$ & 11 & 6 & 5 & 3 & 2 \\
\hline Sensibility (\%) & 84.6 & 76.9 & 38.5 & 23.1 & 15.4 \\
\hline Specificity (\%) & 22.2 & 52.2 & 67.8 & 71.1 & 75.6 \\
\hline PPV (\%) & 13.6 & 18.9 & 14.7 & 10.3 & 8.3 \\
\hline NPV (\%) & 90.9 & 94 & 88.4 & 86.5 & 86.1 \\
\hline Detection rate (\%) & 10.7 & 5.8 & 4.8 & 2.9 & 1.9 \\
\hline Error ratio (\%) & 6.6 & 7.2 & 7.4 & 12 & 16.5 \\
\hline Combined error (\%) & 69.9 & 41.7 & 35.9 & 34.9 & 32.0 \\
\hline Efficiency (\%) & 32 & 55.3 & 64.1 & 65.1 & 68 \\
\hline Youden index & 0.07 & 0.30 & 0.06 & 0 & 0 \\
\hline
\end{tabular}

PPV, positive predictive value; NPV, negative predictive value; TrP, true positive. 


\section{DISCUSSION}

The early diagnosis of CNS involvement in malignant diseases is difficult and traditionally based on clinical evidence and the presence of malignant cells in $\mathrm{CSF}^{17-22}$.

Methods with more sensibility and specificity than the cellular morphology are necessary to correctly identify malignant cells in the $\mathrm{CSF}^{23,24}$. Although CSF cytology is useful, malignant cells are not detected in as many as one third of patients who have compelling clinical or radiographic evidence of neoplastic meningitis. Novel assays are being tested that may enhance the early identification of malignant cells in CSF. Currently, the diagnosis occurs after the onset of neurologic manifestations and heralds a rapidly fatal course for most patients ${ }^{21}$. Imunocytochemistry techniques, immunophenotipage and biochemical

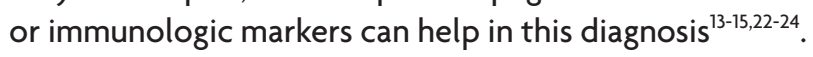
The analysis of CSF biochemical and cellular characteristics, although not specific for the diagnosis of malignant involvement of CNS, are important ${ }^{1}$ and can help for the diagnosis of CNS malignant disease when associated with other clinical or biomarker characteristics.

In this study CSF ferritin levels were analyzed as a biochemical marker for the diagnosis of CNS involvement in malignant diseases. CSF ferritin levels were higher at the group with CNS malignant involvement proved by the presence of malignant cells in CSF, than in the group with inflammatory CNS diseases. The number of erythrocytes (RBC) in CSF correlates with CSF ferritin levels ${ }^{9,10,25}$, because of this we excluded the CSF samples with more than $50 \mathrm{RBC} / \mathrm{mm}^{3}$.

Ferritin is found in concentrations of up to $10 \mathrm{ng} / \mathrm{mL}$ in normal CSF, other studies report lower levels as $2.3 \mathrm{ng} /$ $\mathrm{mL}$ with an upper limit at $5.5 \mathrm{ng} / \mathrm{mL}^{10}$. In this study the CSF ferritin median levels at the group without neoplastic cells was $13.0 \pm 16.9 \mathrm{ng} / \mathrm{mL}$.

The best cut-off of CSF ferritin for the diagnosis of CNS involvement in malignant diseases is $20 \mathrm{ng} / \mathrm{mL}$. With this cut-off sensibility and specificity have almost similar values and the Youden index is higher than with other values.

Lower CSF ferritin values (less then $20 \mathrm{ng} / \mathrm{mL}$ ) could indicate that there is less chance of having a CNS malignant infiltration, because the negative predictive value is high with this CSF ferritin cut-off. Higher cut-off values sensibility decreases although specificity increases and Youden index is zero, this means that the test is no better than chance. The Youden index completely ignores the effect of prevalence on the test situation.

Although an increased CSF ferritin does not indicate the diagnosis of CNS malignant neoplasic infiltration, with low ferritin levels CNS malignant infiltrations seems less probable.
In this study CSF ferritin measurement seems to be not useful in the differential diagnosis of malignant CNS involvement and CNS inflammation because in both conditions CSF ferritin levels are increased confirming the results of previous studies ${ }^{8,9}$. Also, CSF ferritin was higher in the group with bacterial meningitis than the other groups, in accordance with previous papers ${ }^{10}$. Ferritin metabolism and blood brain barrier, could explain the great increase on the group with acute bacterial meningitis. This could be related to the blood brain barrier disruption that is present in acute bacterial meningitis, probably with a leakage of ferritin from blood to CSF. Although for some authors CSF ferritin can be considered to be derived almost exclusively from sources within the CNS itself, as even in cases of severely impaired blood CSF barrier function, the amount of ferritin present in CSF by far exceeds the amount explicable by its molecular size $\mathrm{e}^{25}$. The association of CNS malignant involvement and bacterial meningitis could occur because immunosuppressions by chemotherapy, corticosteroids, BMT or by the malignant process itself. In theses cases CSF ferritin could not help as a marker of malignant neoplasic infiltrations, because is increased in both cases.

Ferritin is a macromolecule with molecular weight of $450 \mathrm{kD}$, occurring in at least 20 isoferritin variants. Each ferritin molecule is thought to consist of a spherical protein shell made up of 24 subunits with a variable amount of iron as a core of ferricoxide-phosphate. Ferritin that is not combined with iron is called apoferritin. Ferritin is the main intracellular iron storage protein, keeping it in a soluble and non-toxic form. Inside the ferritin shell, iron ions form crystallites together with phosphate and ions. Each ferritin complex can store about 4500 iron (Fe 3+) ions. It has been demonstrated that the ferritin molecule, when fully saturated, may consist of over $20 \%$ iron by weight ${ }^{26}$. It serves as iron storage proteins in liver, spleen and bone marrow. While the serum ferritin concentration reflects the iron load of the organism, information on the origin and relevance of CSF ferritin is scarce. Ferritin is slightly elevated in CNS inflammations, stroke and tumor infiltration and exceeding serum values after subarachnoid hemorrhage. There was not correlation between CSF and serum ferritin concentration and no correlation between CSF/ serum ferritin ratio and the albumin ratio ${ }^{25}$. The concentrations in the serum and CSF were independent, but that in CSF correlated with its total protein content ${ }^{10}$. The immunoblot after isoelectric focusing showed 6 to 10 ferritin bands at an IP 5.0 to 6.0, corresponding to the properties of basic storage ferritins. Very high ferritin content was observed in macrophages after subarachnoid hemorrhage, and moderately high content in tumor cells; leukocytes were weakly ferritin positive on membrane surfaces. 
The cellular ferritin content, but not the cell count correlates to CSF ferritin concentration in the corresponding diseases ${ }^{27}$. A macromolecule such as ferritin can cross the blood-CSF barrier only in traces. Whereas an intact bloodCSF barrier can be expected to enable the passage of only $0.1 \%$ of a $450 \mathrm{kD}$ protein. The ferritin found in CSF is predominantly derived from sources within the CNS itself. Apart from cerebral parenchyma, at least in cases with pleocytosis, CSF cells may account for ferritin production. Degradation of erythrocytes by macrophages after subarachnoid hemorrhage yields high amounts of surplus iron, which must be stored as non-toxic basic ferritin. High concentrations are released into CSF, which facilitate the discrimination of genuine hemorrhage and traumatic spinal puncture ${ }^{25}$.

In malignant process possible mechanisms responsible for increased serum ferritin levels are chronic inflammation secondary to the malignant process and increased secretion of ferritin by the malignant cells ${ }^{3,4,28,29}$. The higher concentration of CSF ferritin in the group with $>50 \%$ of neoplasic cells described in the present study are in accordance with the hypothesis of ferritin production by the neoplasic cells.

We conclude that CSF ferritin with the cut-off of 20 $\mathrm{ng} / \mathrm{mL}$ could be an important CSF biomarker adding to the diagnosis of CNS malignant infiltration. In contrast to many other CSF proteins, the interpretation of CSF ferritin concentrations does not require the taking into account of plasma ferritin or the permeability of blood-CSF barrier $^{25}$. With the present study no final conclusion can be made regarding the behavior of CSF ferritin in relation to the time of onset of infiltration.

\section{REFERENCES}

1. Almeida SM, Nakanishi E, Conto AJ, et al. Cerebrospinal fluid cytological and biochemical characteristics in the presence of CNS neoplasia. Arq Neuropsiquiatr 2007;65:803-809.

2. Van Oostenbrugge RJ, Twijnstra A. Presenting features and value of diagnostic procedures in leptomeningeal metastases. Neurology 1999; 53:382-385.

3. Matzner Y, Konijn AM, Hershko C. Serum ferritin in hematological malignancies. Am J Hematol 1980;9:13-22.

4. Patel R, Shah PC, Vohra RM, et al. Serum ferritin levels in hematological malignant neoplasm. Arch Pathol Lab Med 1980;104:509-512.

5. Aulbert E, Schimidt CG. Ferritin: a tumor marker in myeloid leukemia. Cancer Detect Prev 1985;8:297-302.

6. Dormer MH, Abel U, Fritze D, et al. Serum ferritin in relation to the course of Hodgkin's disease. Cancer 1993;529:2308-2312.
7. Dillmann E, López-Karpovitch X, Alvarez-Hernández X, et al. Ferritin and malignant hemopathies: I. Ferritin in cerebrospinal fluid as an indicator of central nervous system leukemic involvement. Rev Invest Clin 1982;34:95-98.

8. Vicente V, Gonzalez M, Lopez-Borrasca A. Cerebrospinal fluid levels beta02 microglobulin and ferritin in lymphoproliferative disorders. Acta Paediatr Scand 1982;71:325-326.

9. Zandman-Goddard G, Matzner Y, Konijn AM, et al. Cerebrospinal fluid ferritin in malignant CNS involvement. Cancer 1986;58:1346-1349.

10. Sindic CJ, Collet-Cassart D, Cambiaso CL, et al. The clinical relevance of ferritin concentration in the cerebrospinal fluid. J Neurol Neurosurg Psychiatry 1981;44:329-333.

11. Balm M, Hammack J. Leptomeningeal carcinotasis: presenting features and prognostic factors. Arch Neurol 1996;53:626-632.

12. Fishman RA. Cerebrospinal fluid in diseases of the nervous system. Philadelphia: WB Saunders 1992.

13. Bossolasco S, Nilsson A, Milito A, et al. Soluble CD23 in cerebrospinal fluid: a marker of AIDS related non-Hodgkin's lymphoma in the brain. AIDS 2001;15:1109-1113.

14. Murare S, Saio M, Takenaka K, et al. Increased levels of CSF soluble CD27 in patients with primary central nervous system lymphoma. Cancer Lett 1998;13:2181-2186.

15. De Luca A, Antinori A, Cingolani A, et al. Evaluation of cerebrospinal fluid EBV-DNA and IL-10 as markers for in vivo diagnosis of AIDS-related primary central nervous system lymphoma. Br J Haematol 1995; 90:844-849.

16. Galen RS, Gambino SR. Beyond normality: the predictive value and efficiency of medical diagnoses. New York: John Wiley \& Sons 1975.

17. Glass JP, Melamed M, Chernik NL, et al. Malignant cells in cerebrospinal fluid (CSF): the meaning of a positive CSF cytology. Neurology 1979;29:1369-1375.

18. Watson CW, Hajdu SI. Cytology of primary neoplasm of the central nervous system. Acta Cytol 1977;21:40-47.

19. Sá MJ, Vaz R, Cruz C. Cerebrospinal fluid cytomorphologic findings in 41 intracranial tumors. Arq Neuropsiquiatr 1995;53:218-226.

20. Glantz MJ, Cole BF, Glantz LK, et al. Cerebrospinal fluid cytology in patients wiyh cancer: minimizing false-negative results. Cancer 1998;82: 733-739.

21. Kim L, Glantz MJ. Neoplastic meningitis. Curr Treat Options Oncol 2001;2:517-527.

22. Freilich RJ, Krol G, De Angelis LM. Neuroimaging and cerebrospinal fluid cytology in the diagnosis of leptomeningeal metastasis. Ann Neurol 1995:3851-3857.

23. Sampath P, Weaver CE, Sungarian A, et al. Cerebrospinal fluid (vascular endothelial growth factor) and serologic (Recoverin) tumor markers for malignant glioma. Cancer Control 2004;11:174-180.

24. Hug A, Storch-Hagenlocher B, Haas J, et al. Single-cell PCR analysis of the immunoglobulin heavy-chain CDR3 region for the diagnosis of leptomeningeal involvement of B-cell malignancies using standard cerebrospinal fluid cytospins. J Neurol Sci 2004;219:83-88.

25. Wick M, Fink W, Pfister W, et al. Ferritin in cerebrospinal fluid differentiation between central nervous system haemorrhage and traumatic spinal puncture. J Clin Pathol 1988;41:809

26. Crichton RR. Ferritin: structure, synthesis and function. N Engl J Med 1971;284:1413-1422.

27. Wick M, Huber M, Bayerl B, et al. Ferritin in CSF: characterization and possible origin. In: Felgenhauer K, Holzgraefe M, Prange HW (Eds.). CNS Barriers and moderns CSF diagnosis. Weinheim Verlagsgesellschaft 1993:274-277.

28. Harrison PM, Hoy TG, Macara IG, et al. Ferritin iron uptake and release: structure-function relationships. Biochem J 1974;143:445-451.

29. White GP, Worwood M, Parry D. Ferritin synthesis in normal and leukemic leukocites. Nature 1974;250:584-586. 